\title{
Increasing Awareness of Health Protocols During Covid-19 Pandemic at SDN Setiamulya
}

\author{
Meiliana Nurfitriani", Budi Hendrawan, Mohammad Fahmi Nugraha, Yopa Taufik Saleh, \\ Devi Annisa Rahmawati, Teti Nurul Fathiyati, Eki Hilman Rasyid, Gumgum Gumilar, \\ Ismail
}

rogram Studi Pendidikan Guru Sekolah Dasar, Fakultas Keguruan dan IImu Pendidikan Universitas Muhammadiyah Tasikmalaya, Jl. Tamansari, Km. 2,5 Kec. Tamansari Kota Tasikmalaya *Corresponding Author: meiliana.nurfitriani@umtas.ac.id

\begin{abstract}
A bstrak
This Community Partnership Program (PKM) aims to increase primary students' understanding of the dangers of Covid 19 and educate them on how to prevent it through correct health protocols and being able to implement a healthy lifestyle. The targets of this program are high grade of primary students, namely grade 4 , grade 5 , and grade 6 . The method used in this education is storytelling in an interactive online style via zoom platform. Stories are conveyed in English with simple language and sentences to make them easier to understand, besides that the delivery is combined with Indonesian so that children understand the meaning and are able to imitate certain sentences and movements well. The implementation of this program makes students enthusiastic and excited, especially using English. The students feel cooler when they listen to stories and speak English. Children enthusiastically mimic, sing and perform healthy protocol movements in interesting ways. Thus, children are able to understand the contents of the stories and values that are conveyed, so that they are able to apply them to new good habits in the era of new normal life. As conclusion, the storytelling method is able to provide a good understanding of the Covid 19 pandemic for children, so that awareness emerges to apply health protocols in their daily life.
\end{abstract}

Article Info

\section{Article History:}

Received 1 November 2021

Revised 10 November 2021

Accepted 20 November 2021

Available online 15 January 2022

\section{Keywords:}

Covid-19,

Health protocol,

Storytelling

\section{INTRODUCTION}

During the current COVID-19 pandemic, efforts to maintain health are very important things to do so that the spread of the virus can be stopped immediately. The government continues to strive to break the chain of the spread of the COVID-19 virus in various ways, such as implementing Large-Scale Social Restrictions (PSBB) by restricting activities in public places or facilities, closing schools and workplaces, restricting religious activities, and restricting transportation modes. However, efforts to break the chain of this epidemic are not only the task of the government alone, but all levels of society.

The implementation of health protocols is currently the main thing that must be done, such as using a mask when traveling/doing activities outside the home, frequently washing hands with soap, using hand sanitizer as often as possible after handling an object, doing social and physical distancing or maintaining a distance. But in reality, people often ignore these health protocols by finding crowds of people in public places, many of whom are not even wearing masks. Therefore, it is very important to raise public awareness about the 
application of health protocols, especially for children who still lack understanding of the COVID-19 outbreak.

Children's understanding of covid 19 is still very limited, this can be seen from the many children who play without wearing a mask, even in the center of a crowd, often they take off their masks for stuffy reasons, besides that there are still many children who whine to their parents to go to school even though the government have implemented the rules of studying at home, playing in public places, asking for a walk to the mall, or eating and drinking in the same place with friends, where it is very risky for disease transmission. Therefore, a correct understanding of this epidemic and awareness of the importance of health protocols with methods that are easily understood by children is urgently needed.

One effort that can be done is to use the storytelling method. Storytelling is a method that is able to change the thinking of someone who hears it because in the story there are various kinds of information, knowledge, or experiences that are conveyed in a fun way. This is in accordance with the theory expressed by Miller (2011) that a story is able to give meaning to life, express values, teach youth, and convey culture. Stories also connect elements in a person's self, experience and life. Cakra (2012) also said that one of the benefits of storytelling is as a means to convey advice and form good behavior in accordance with the values contained in the story. Therefore, the socialization program to increase awareness of health protocols using the storytelling method at SDN Sukamulya is expected to be able to help increase awareness of health protocols during the COVID-19 pandemic, especially for children.

\section{METHOD}

The program to increase awareness of health protocols during the COVID-19 pandemic was carried out at Setiamulya Elementary School on JI. Sukamaju, Mulyasari, Tamansari District, Tasikmalaya, West Java.

The method used in this program is storytelling. Storytelling is a narrative skill in an interesting way such as accompanied by singing or music or other accompaniment that can be learned orally and has personal and intellectual values in it (Fakhrudin: 2003). This program is intended for students starting from grade 4 to grade 6 SD online using the zoom platform. This is in accordance with the government's recommendation to study online at home. This program will be implemented for 3 days and is scheduled for 1 day for 1 class with a duration of 30 minutes/class. The following is the program schedule that will be implemented:

Table 2. Schedule of Health Protocol Awareness Education Programs during the Covid 19 Pandemic Through Storytelling at Setiamulya 1 Elementary School

\begin{tabular}{|c|c|c|c|}
\hline Day & Time & Class & Person Responsible \\
\hline Monday & $09.00-09.30$ & 4 & $\begin{array}{c}\text { Devi } \\
\text { Eki Hilman Rasyid }\end{array}$ \\
\hline Tuesday & $09.00-09.30$ & 5 & $\begin{array}{c}\text { Devi } \\
\text { Eki Hilman Rasyid }\end{array}$ \\
\hline Wednesday & $09.00-09.30$ & 6 & $\begin{array}{c}\text { Devi } \\
\text { Eki Hilman Rasyid }\end{array}$ \\
\hline
\end{tabular}

The content of the stories conveyed includes realistic conditions regarding covid 19, good and correct hand washing procedures according to WHO, steps to implement health protocols such as the use of masks and physical distancing, as well as activities that can be done during a pandemic. The hope of this program is that children can be more aware of the 
presence of the corona virus around them so that they always apply a clean and healthy lifestyle.

The process of delivering storytelling is carried out directly or live by the person in charge, which in this case is students who are given storytelling assignments according to a schedule through the zoom platform. Thus the process of telling the story will take place more attractively and communicatively so that students can be directly involved in the story.

\section{PROGRAM ELIGIBILITY}

This program is one of the efforts to educate the public, especially children, to understand the importance of implementing health protocols during the COVID-19 pandemic in a language that is simpler and easily accepted by their understanding. The task of a teacher/educator is not only to convey subject matter, but also to convey an understanding of the real situation that is happening in society, moreover the COVID-19 pandemic is a global problem that requires the cooperation of all levels of society in overcoming it. So the Elementary School Teacher Education Study Program at the University of Muhammadiyah Tasikmalaya wants to play an active role in overcoming these problems.

In implementing this program, of course, in collaboration with several experts who have certain expertise as technical teams and drafters, including English lecturers who have a role in making story concepts more attractive, communicative and easy for children to understand, pedagogic lecturers and basic education lecturers who play a role in making story concepts. to suit the characteristics of students and the goals to be achieved, as well as PLH and Learning Media lecturers who play a role in conceptualizing the content of stories related to Health protocols and processing these stories into multimedia (video) form.

\section{RESULTS AND DISCUSSION}

The health protocol awareness education program during the covid 19 pandemic through storytelling was carried out at SDN Setiamulya on November 20,2020. The targets for this education program were high grades, namely grades 4, 5 and 6 . already able to understand a story told by another person orally. In addition, the language used in this storytelling uses Indonesian and is combined with English as a form of basic introduction so that students do not feel too foreign to English at the next level.

This educational program is carried out online through the Zoom platform. Initially, this program was scheduled to be implemented for 3 days, with 1 day for each class. However, due to several obstacles related to the lack of students and parents who have gadgets, as well as lack of knowledge about how to use the zoom platform, only a few students are ready to take part in this educational program. From grade 4, there are 5 students, from grade 5 there are 14 students, and from grade 6 there are 6 students. The total number of students who participated in the education program for implementing this health protocol was 25 students. Therefore, this program is carried out simultaneously with these students from grade 4 to grade 6 for 1 hour following preparation, starting at 09.00 until 10.00 WIB.

The following is a list of names of students who participated in the education program for implementing health protocols during the pandemic through storytelling.

This educational program is guided by 2 storytellers using media in the form of hand puppets according to the characters in the story. The use of these media aims to make the stories displayed by storytellers more alive and feel real so that students are able to understand the storyline that is displayed in two languages and be able to capture the moral message contained in the story. The language used is also simple language like the language that is 
often used in everyday life, so that the use of English in storytelling is still acceptable and easy to follow the pronunciation. The way of presentation is also done more communicatively so that students can follow each stage of the story.

The story brought by the storyteller is entitled "I'm Strong Against Corona". The story aims to provide a good understanding of the corona virus so that students do not feel anxious or underestimate the virus. The story shows how to apply health protocols and how to wash hands properly and correctly through songs followed by unique movements.

In practice, this program can be implemented very well. This can be seen from the results of the questionnaire given to students after the end of the program. All students stated that storytelling about the application of health protocols during the COVID-19 pandemic was very enjoyable. In addition, 92\% of students stated that the storytelling was easy to understand even though it used two languages. In the implementation process, students enthusiastically participated in the event from beginning to end. They enthusiastically paid attention to the stories presented, even communicated and answered every question that was asked, and cheerfully followed the hand washing movements accompanied by songs. Therefore, this program runs very pleasantly.

Storytelling is a very effective method used to educate students about the application of health protocols. Based on the questionnaire given after the education program, it was found that during this pandemic period, $100 \%$ of students left the house if something was needed, such as buying food/basic materials, medicines and so on. The questionnaire was given to students after 7 days of implementing the educational program to see the impact of the program, whether the students understood it and implemented it in their daily lives. After this educational program, $96 \%$ of students always wear masks, maintain distance/physical distancing when leaving the house, and wash their hands with soap/hand sanitizer after activities outside the home. In addition, $100 \%$ of students also began to implement healthy lifestyle behaviors to maintain their body's immunity by always exercising and eating nutritious and healthy food.

The following is an illustration of the percentage of implementation of health protocols for SDN Setiamulya students after the health protocol education program during the COVID19 pandemic through storytelling based on the results of the questionnaire.

In other words, the health protocol education program through storytelling has a very good impact for students, especially in the new normal period to become a good habit.

The output of this program is in the form of scientific articles published in the Abdimas journal. The results of this program were disseminated in the national seminar event of the Muhammadiyah University of Purwokerto so that its benefits could be felt more broadly. This program also produces learning videos related to storytelling on the application of health protocols during the COVID-19 pandemic with the title "I am Strong Against Corona". It is hoped that this video can be watched and used by children anytime and anywhere with the aim of educating them regarding the understanding of the corona virus and how to apply the correct health protocols so that a healthy lifestyle can be used as a new lifestyle in the new normal era.

\section{CONCLUSION}

Education on health protocols during the COVID-19 pandemic through storytelling is very effective for elementary school children. The health protocol education program through storytelling with the title "I am Strong Against Corona" which was carried out at Setiamulya Elementary School had a positive impact on children's understanding of the corona virus, 
thereby increasing knowledge about how to deal with the virus and reducing anxiety levels and ignorance towards the virus. Children become more alert and obedient in maintaining health protocols such as wearing masks, maintaining distance, and washing hands with soap after activities from outside, as well as practicing healthy lifestyles such as diligently exercising and eating healthy foods. Storytelling which is presented in 2 languages, namely Indonesian and English, not only provides a fun new experience for children in learning through stories that are presented to take the positive message, but can also improve children's language skills, especially foreign languages as a form of basic introduction for students. primary school.

\section{REFERENCES}

Cakra, Ki Heru. 2012. Mendongeng dengan Mata Hati. Mumtaz Media: Surabaya.

Desmita. 2010. Psikologi Perkembangan Peserta Didik. Bandung: PT. Remaja Rosda Karya.

Fakhrudin, Muhammad. 2003. Cara Mendongeng. Pelatihan Teknik Mendongeng bagiguru TK sekabupaten Purworejo. Universitas Muhammadiyah Purworejo.

Miller, Erric. 2011. Theories of story and storytelling. Tersedia: http://www.storytellingandvideoconferencing.com/67.pdf diunduh tanggal 18 Juli 2020 


\section{ATTACHMENT}

Table 3. List of Names of SDN Setiamulya Students Who Follow Health Protocol Education Program in Pandemic Period

\begin{tabular}{|c|l|l|}
\hline Number & \multicolumn{1}{|c|}{ Student's name } & \multirow{2}{*}{ Class } \\
\hline 1 & Siska Apriani & \\
\hline 2 & Aulia Khansa & \\
\hline 3 & Setiawan & \\
\hline 4 & Fazmi Sendi & \\
\hline 5 & Zahira Nur Islami & \\
\hline 6 & Khalisa & \\
\hline 7 & Anaya & \\
\hline 8 & Anfaunisa & \\
\hline 9 & Riza & \\
\hline 10 & Azman & \\
\hline 11 & Puja & \\
\hline 12 & Alya \\
\hline 13 & M. Raihan & \\
\hline 14 & Alya & \\
\hline 15 & Hamzah & \\
\hline 16 & Siti Kania \\
\hline 17 & Vitha \\
\hline 18 & Renata \\
\hline 19 & Zaki & \\
\hline 20 & Adik \\
\hline 21 & Fadlan \\
\hline 22 & Fardhan \\
\hline 23 & Zistan \\
\hline 24 & Galang \\
\hline 25 & Akbar \\
\hline & & \\
\hline
\end{tabular}




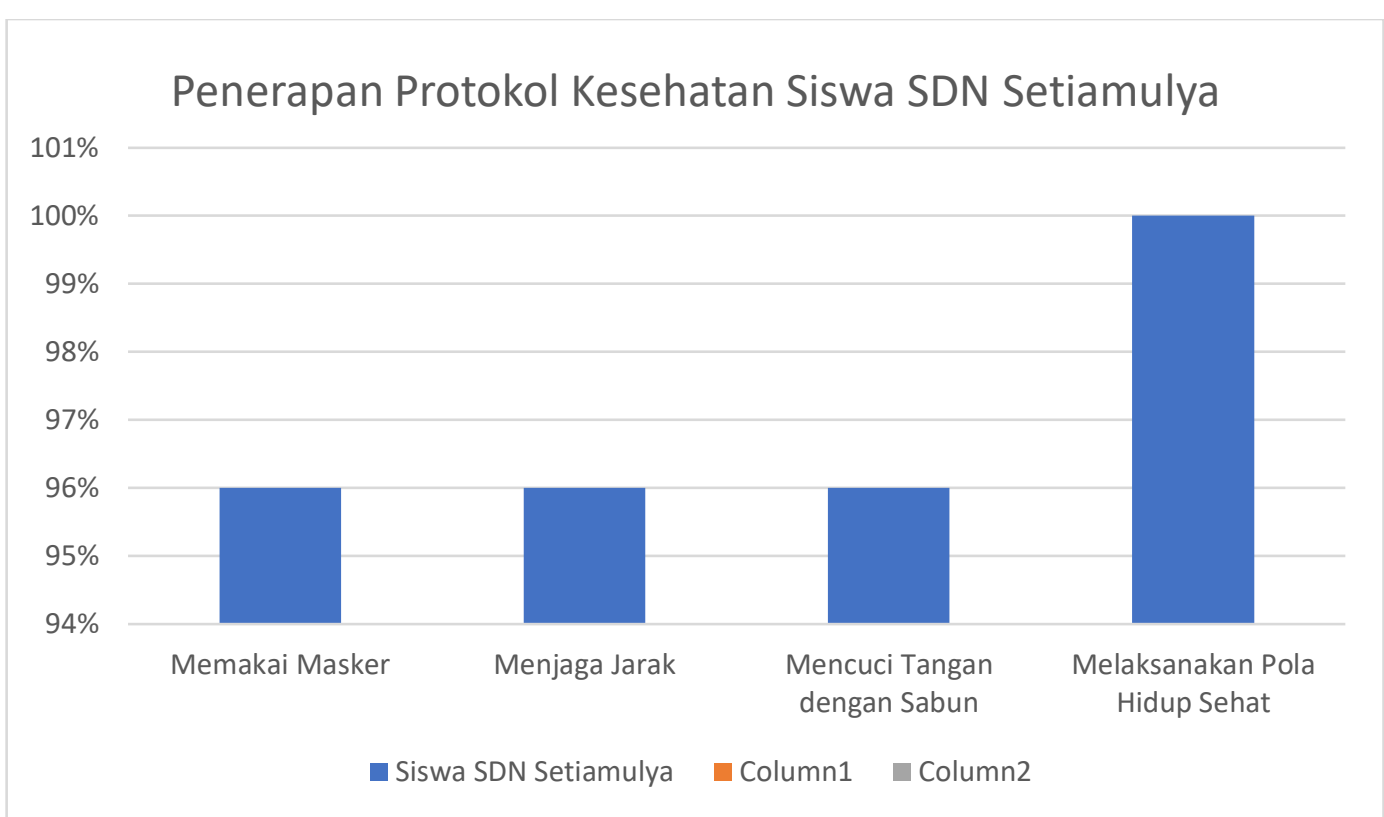

Figure 1. Percentage of Health Protocol Implementation of Setiamulya Elementary School Students After Health Protocol Education Program Through Storytelling 